\title{
Случай персонализированного подхода к терапии железодефицитной анемии
}

\author{
Жарылкасынова Г. Ж. \\ Бухарский государственный медицинский институт, Бухара, Узбекистан
}

Ключевые слова: полиморфизм гена MDR1; железодефицитная анемия; генотипирование

Для цитирования:

Жарылкасынова Г.Ж. Случай персонализированного подхода к терапии железодефицитной анемии // Фармакогенетика и фармакогеномика. 2020;(2):34. (In Russ). DOI: 10.37489/2588-0527-2020-2-34

Введение. В настоящее время большой интерес учённых привлекает изучение полиморфизма гена MDR1, который детерминирует синтез гликопротеина Р, являющегося активным транспортёром лекарственных веществ в клетках. Несмотря на то что до сих пор в литературе не удаётся найти работ по изучению роли полиморфизма гена MDR1 в степени усвоения препаратов железа, было доказано, что при наличии определённых изоформ данного гена активность транспортёра бывает сниженной, в частности, ряд исследований показали низкую активность гликопротеина Р при генотипе СС гена C3435T MDR1.

Описание клинического случая. Пациентка, 22 года, страдает железодефицитной анемией средней степени тяжести алиментарного генеза, без сопутствующей патологии желудочно-кишечного тракта. Ранее принимала препарат железа (II) в виде Феррум лека (железа (III) гидроксид полимальтозат) 100 мг 1 раз в сутки в течение 3 месяцев. В динамике отмечался незначительный подъём уровня гемоглобина с 75 г/л до 82 г/л.

В момент осмотра предъявляет жалобы на слабость, головокружение, «мушки перед глазами». Объективно: отмечается бледность кожных покровов и видимых слизистых. Общий анализ крови: гемоглобин - 80 г/л; эритроциты $-3,1$; гематокрит 42; цветной показатель - 0,8 ; ретикулоциты $-3 \%$; средняя концентрация гемоглобина в эритроците 1,6 ; средний объём эритроцита $-1,3$ мкм³. Анализ $^{3}$ крови на ферритин - 150 мкг/л.

Тип вмешательства. В результате генотипирования было определено, что у пациентки имеется генотип CС гена C3435T MDR1.

Тип персонализации. На основании данных лабораторных анализов и генотипирования пациентке была назначена персонализированная ферротерапия с повышенной дозой препарата железа (III) в виде Мальтофера (железа (III) гидроксид полимальтозат) 100 мг 2 раза в сутки в течение 3 месяцев.

Динамика в результате персонализации. В динамике через 1 месяц ферротерапии отмечено снижение субъетивной симптоматики (с 6 баллов по визуально-аналоговой шкале до 4 баллов), снижение проявлений сидеропенического синдрома, прирост уровня гемоглобина до 95 г/л; эритроцитов - до 3,3; гематокрита - до 44; цветного показателя - до 0,9; ретикулоцитов - до $5 \%$; средней концентрации гемоглобина в эритроците - до 1,8 ; среднего объёма эритроцита до 1,4 мкм³ и ферритина - до 180 мкг/л.

В динамике через 3 месяца ферротерапии отмечено снижение субъетивной симптоматики (с 6 баллов по визуально-аналоговой шкале до 1 балла), купирование проявлений сидеропенического синдрома, прирост уровня гемоглобина до 115 г/л, эритроцитов - до 3,6; гематокрита - до 46; цветного показателя - до 1,0; ретикулоцитов - до $6 \%$; средней концентрации гемоглобина в эритроците - до 1,9; среднего объёма эритроцита - до 1,5 мкм $^{3}$ и ферритина - до 220 мкг/л.

Заключение. Полученные данные свидетельствуют о том, что наличие генотипа CC гена C3435T MDR1, который детерминирует менее активную форму гликопротеина Р, может быть возможной причиной низкой степени усвоения препарата железа, что требует дальнейших исследований. Более глубокие исследования позволят лучше понять роль клеточных транспортёров и генов, детерминирующих их в процессе активного транспорта железа в клетках и тем самым позволят вносить необходимые корректировки в индивидуальный план лечения пациентов в соответствии с их фармакогенетическими особенностями. 